\title{
A long-term "memory" of HIF induction in response to chronic mild decreased oxygen after oxygen normalization Chandrashekhar D Kamat ${ }^{\dagger 1}$, Jessica E Thorpe ${ }^{\dagger 1}$, Satyendra S Shenoy ${ }^{1,3}$, Antonio Ceriello ${ }^{2}$, Dixy E Green ${ }^{1}$, Linda A Warnke ${ }^{1}$ and Michael A Ihnat*1
}

\author{
Address: ${ }^{1}$ Department of Cell Biology, University of Oklahoma Health Sciences Center, Oklahoma City, OK 73104, USA, ${ }^{2}$ Warwick Medical \\ School, University of Warwick, Gibbett Hill, Coventry CV4 7AL U.K and ${ }^{3}$ Department of Pharmacology, Nicholas Piramal Research Centre, \\ Mumbai, India \\ Email: Chandrashekhar D Kamat - shekhar-kamat@ouhsc.edu; Jessica E Thorpe - jessica-thorpe@ouhsc.edu; Satyendra S Shenoy - satyendra- \\ shenoy@ouhsc.edu; Antonio Ceriello - antonio.ceriello@warwick.ac.uk; Dixy E Green - dixy-green@ouhsc.edu; Linda A Warnke - linda- \\ warnke@ouhsc.edu; Michael A Ihnat* - michael-ihnat@ouhsc.edu \\ * Corresponding author †Equal contributors
}

Published: 18 January 2007

BMC Cardiovascular Disorders 2007, 7:4 doi:10.1 186/147/-226I-7-4

This article is available from: http://www.biomedcentral.com/|47|-226I/7/4

(C) 2007 Kamat et al; licensee BioMed Central Ltd.

This is an Open Access article distributed under the terms of the Creative Commons Attribution License (http://creativecommons.org/licenses/by/2.0), which permits unrestricted use, distribution, and reproduction in any medium, provided the original work is properly cited.
Received: 23 October 2006

Accepted: 18 January 2007

\begin{abstract}
Background: Endothelial dysfunction (ED) is functionally characterized by decreased vasorelaxation, increased thrombosis, increased inflammation, and altered angiogenic potential, has been intimately associated with the progression and severity of cardiovascular disease. Patients with compromised cardiac function oftentimes have a state of chronic mild decreased oxygen at the level of the vasculature and organs, which has been shown to exacerbate ED. Hypoxia inducible factor (HIF) is a transcription factor complex shown to be the master regulator of the cellular response to decreased oxygen levels and many HIF target genes have been shown to be associated with ED.
\end{abstract}

Methods: Human endothelial and aortic smooth muscle cells were exposed either to A) normoxia $\left(21 \% \mathrm{O}_{2}\right)$ for three weeks, or to $\left.\mathrm{B}\right)$ mild decreased oxygen $\left(15 \% \mathrm{O}_{2}\right)$ for three weeks to mimic blood oxygen levels in patients with heart failure, or to C) mild decreased oxygen for two weeks followed by one week of normoxia ("memory" treatment). Levels of HIF signaling genes (HIF-I $\alpha$, HIF-2 $\alpha$, VEGF, BNIP3, GLUT-I, PAI-I and iNOS) were measured both at the protein and mRNA levels.

Results: It was found that chronic exposure to mild decreased oxygen resulted in significantly increased HIF signaling. There was also a "memory" of HIF-I $\alpha$ and HIF target gene induction when oxygen levels were normalized for one week, and this "memory" could be interrupted by adding a small molecule HIF inhibitor to the last week of normalized oxygen. Finally, levels of ubiquitylated HIF-I $\alpha$ were reduced in response to chronic mild decreased oxygen and were not full restored after oxygen normalization.

Conclusion: These data suggest that HIF signaling may be contributing to the pathogenesis of endothelial dysfunction and that normalization of oxygen levels may not be enough to reduce vascular stress. 


\section{Background}

Endothelial dysfunction has been shown to play a causative role in atherosclerosis [1], ischemic heart disease [2], coronary artery disease [3], peripheral neuropathy [4], diabetic cardiomyopathy [5], erectile dysfunction [6] and even ischemia/reperfusion subsequent to myocardial infarction [7]. Endothelial dysfunction is a generalized syndrome characterized by attenuated vasodilation [8], due at least in part to decreased available nitric oxide (NO) [9], a concomitant buildup of reactive species [10] and stimulation of vascular stress pathways [11]. Another characteristic of endothelial dysfunction is an altered angiogenic response [12], which can affect tissue vascularity, immune cell infiltration, blood flow patterns, and wound healing (reviewed in [11]). If the blood vessels cannot supply the tissues with blood, a state of relative decreased oxygen ensues further contributing to endothelial dysfunction [13].

Hypoxia induces expression of hypoxia inducible factor (HIF), a transcription factor complex shown to be the master regulator of the cellular response to decreased oxygen levels [14]. The HIF proteins belong to a family of basic helix-loop-helix transcription factors. The HIF complex is a heterodimer consisting of a regulated $\alpha$ subunit and a constitutive $\beta$ subunit [15]. In normoxic environments, the $\alpha$ subunit is hydroxylated at proline residues [16], which targets it for ubiquitylation, by proteins such as Von Hippel-Lindau [17], ultimately resulting in its degradation by the proteasome. There are two known HIF $\alpha$ subunits which stimulate transcription, HIF- $1 \alpha$ and HIF$2 \alpha$, in addition to a third $\alpha$ subunit (HIF- $3 \alpha$ ) lacking the DNA binding domain which appears to compete with HIF- $1 \alpha$ and HIF- $2 \alpha$ for $\beta$ subunit binding and acts to inhibit HIF signaling [18]. The HIF- $1 \alpha /$ HIF-1 $\beta$ heterodimer binds to hypoxia response elements in the regulatory regions of more than 70 target genes such as the vascular endothelial growth factor (VEGF), plasminogen activator inhibitor (PAI-1), inducible nitric oxide synthase (iNOS), erythropoietin, Bcl2/adenovirus EIB 19kD-interacting protein 3 (BNIP3), heme oxygenase-1, and glucose transporter-1 (GLUT-1) [19]. In addition to being regulated by hypoxia, the HIF pathway can be modulated by reactive species [20,21], nitric oxide [22], metals [23,24], cytokines [25], and growth factor signaling through phosphatidylinositol 3-kinase [26] and mitogen activated protein (MAP) kinase pathways [27].

The idea that vascular stress has long-lasting effects that perpetuate further damage, even when the stressor is removed, is developing support both in the laboratory [28] and in the clinic [[29-32] 364, 771-7]. For example, it was found that changes in cellular fatty acid metabolism persist for up to 30 hours after oxygen levels are normalized following myocardial ischemia [31]. Clinically, per- sistent benefits of antihypercholesterolemic agents [32] angiotensin converting enzyme (ACE) inhibitors [33], and insulin- and drug-mediated glucose normalization in diabetic patients $[29,30]$ have been observed long after these agents were discontinued, further supporting a what has been termed a "memory" of vascular stress.

The first goal of this paper was to determine whether chronic exposure to mild decreased oxygen $\left(15 \% \mathrm{O}_{2}\right)$ induces the HIF signaling system in blood vessels. The second goal was to examine whether there was a "memory" of HIF signaling induction long after oxygen levels were normalized. To investigate these novel questions, human endothelial and aortic smooth muscle cells were exposed either to A) normoxia $\left(21 \% \mathrm{O}_{2}\right)$ for three weeks, or to B) mild decreased oxygen ( $15 \% \mathrm{O}_{2}$ ) for three weeks, or to $\left.\mathrm{C}\right)$ mild decreased oxygen for two weeks followed by one week of normoxia ("memory" treatment). Levels of HIF signaling genes (HIF-1 $\alpha$, HIF-2 $\alpha$, VEGF, BNIP3, GLUT-1, PAI-1 and iNOS) were measured at the protein and mRNA levels. It was found that chronic exposure to mild decreased oxygen resulted in significantly increased HIF signaling. There was also a "memory" of HIF- $1 \alpha$ protein and of several HIF target genes when oxygen levels were normalized for one week after two weeks of mild decreased oxygen, and this "memory" could be interrupted by adding a chemical HIF inhibitor to the last week of normalized oxygen. Finally, levels of ubiquitylated HIF- $1 \alpha$ were reduced in response to chronic mild decreased oxygen and were not full restored after oxygen normalization. Taken together, these data suggest a "memory" of HIF signaling through HIF- $1 \alpha$ in the endothelium in response to chronic mild decreased oxygen and point out the need for more aggressive vascular drug therapies for overcoming the vascular "memory" stress response.

\section{Methods}

\section{Chemicals and cell culture reagents}

All chemicals were purchased from EMD Biosciences (San Diego, CA) unless otherwise noted. Cell culture reagents were purchased from Invitrogen (Carlsbad, CA). Inhibitors were purchased from EMD Bioscience except oxypurinol and ALA, which were from Sigma Chemical and the UCP2 adenovirus, which was a kind gift of Dr. Ming-Hui Zou in Dept. of Endocrinology at OUHSC.

\section{Cell culture}

HMEC-1 human microvascular endothelial cells [34] (obtained from the Centers for Disease Control) were grown in MCDB-131 (pH $7.5 \pm 0.3$ ) media supplemented with 15\% Cosmic Calf Serum (Hyclone, Logan, UT), 2 $\mathrm{mM}$ sodium pyruvate, $2 \mathrm{mM}$ glutamine (Mediatech, Herndon, VA) and penicillin/streptomycin (Hyclone, Logan, UT), 10 ng/ml EGF (Peprotech, Rocky Hill, NJ), 
and $1 \mu \mathrm{g} / \mathrm{ml}$ hydrocortisone in a humidified environment with 5\% carbon dioxide added. HUVEC (human umbilical vein endothelial cells) and ASMC (human aortic vascular smooth muscle cells) (Cambrex, North Brunswick, NJ) were grown in Media-199 (Mediatech, Herndon, VA) supplemented with 15\% Cosmic Calf Serum (Hyclone, Logan, UT), $2 \mathrm{mM}$ sodium pyruvate, $2 \mathrm{mM}$ glutamine (Mediatech, Herndon, VA), penicillin/streptomycin (Hyclone, Logan, UT), 1\% MEM Vitamins (Invitrogen Carlsbad, CA) and 1\% MEM Non-essential Amino Acids (Invitrogen Carlsbad, CA) in a humidified environment with 5\% carbon dioxide added. Cells were incubated with $5 \mathrm{mM}$ glucose (with $25 \mathrm{mM}$ mannitol for osmolarity normalization). Decreased oxygen levels were achieved using a 3-gas incubator (NuAire, Plymouth, MN) and cells fed and passaged in decreased oxygen using a hypoxic glove box (Coy, Ann Arbor, MI). As a control for HIF stimulation, cells were exposed for $4 \mathrm{hr}$ to $2.5 \% \mathrm{O}_{2}$ [35] or to 100 $\mu \mathrm{M}$ deferoxamine for $4 \mathrm{hr}$ [36]. The last week of normoxia was given with or without $62.5 \mu \mathrm{M} \alpha$-lipoic acid (ALA) [37], or with or without $10 \mu \mathrm{M}$ apocynin [38], or with or without $1 \mathrm{mM}$ L-NAME [39], or with or without $10 \mu \mathrm{M}$ oxypurinol [39], or with or without $5 \mu \mathrm{M}$ YC-1 [40], or with or without 25-100 plaque-forming units (PFU)/cell of an UCP2 overexpressing adenovirus [41]. Inhibitors were replaced every other day and 24 hours before the end of the experiment. Cells were grown at 25-30\% confluence in 25 or $75 \mathrm{~cm}^{2}$ flasks until $100 \%$ confluent.

\section{Adenoviral siRNA constructs}

Sequences for the three HIF-1 $\alpha$ small hairpin interfering RNAs are previously published [42-44]. Sequences were synthesized by the OUHSC molecular biology resource facility and ligated first into a shuttle vector (pShuttle$\mathrm{CMV}$, Stratagene, Cedar Creek TX) and then into an adenoviral vector (pAdEasy-1, Stratagene, Cedar Creek TX), cotransformed into competent bacterial cells containing adenoviral plasmid (BJ1583, Stratagene, Cedar Creek TX), linearized and transfected into HEK293 competent cells (Stratagene, Cedar Creek TX). Adenoviral titer was determined by a plaque agarose assay and 50-100 PFU/cells of each virus in serum-free media for $2 \mathrm{hr}$ then serum-containing media replaced. Cells were re-treated every 3 days.

\section{CFDA-AM cell proliferation assay}

After treatment, $5 \mu \mathrm{M}$ 5-carboxyfluorescein diacetate acetoxymethyl ester (CFDA-AM; Molecular Probes, Eugene, OR), a substrate cleaved multiple times by non-specific cellular esterases to form fluorescein, was added for $1 \mathrm{~h}$ at $37^{\circ} \mathrm{C}$. The fluorescence was read on a plate reader (BMG Labtech, Durham, NC) using the fluorescein channel as a marker of cell proliferation [45]. Data were then graphed as a percent of the fluorescence of untreated or normoxic cells.

\section{Co-immunoprecipitation and Western blot}

Cell lysates $(100 \mu \mathrm{g})$ were immunoprecipitated using an antibody against HIF- $1 \alpha(2 \mu \mathrm{g} / 100 \mu \mathrm{g}$ of sample protein) (anti-rabbit, Chemicon, Littleton, CO) and subjected to SDS-PAGE, transferred to nitrocellulose and immunoblotted for ubiquitin (Ubiquitin anti-rabbit 1:1500, Abcam, Cambrige, MA), and immmunoblotted against HIF-1 $\alpha$ (anti-mouse, 1:100, Abcam H1alpha67, Cambrige, MA) used as a control for immunoprecipitation.

Equal amounts of cell lysates $(20-50 \mu \mathrm{g})$ were resolved using 8-12\% SDS-PAGE gels, transferred to $0.2 \mu \mathrm{m}$ nitrocellulose (Schleicher and Schuell), blocked in SuperBlock (Pierce Chemical), incubated with primary antibodies overnight at $4^{\circ} \mathrm{C}$ or for 2 hours at room temperature, washed three times in Tris-buffered saline with $0.25 \%$ Tween-20 (TBST), appropriate secondary antibodies antimouse or anti-rabbit HRP-conjugates (Pierce) diluted in StartingBlock (TBS) Blocking Buffer added at 1:25,000 dilution for $1 \mathrm{hr}$ at RT, washed three times with TBST, SuperSignal Dura chemiluminescence substrate (Pierce Chemical) added, and digital images captured using a charge-coupled device (CCD) camera (Kodak Image Station 4000). Primary antibodies and dilutions used were as follows: anti-HIF-1 $\alpha$ (Chemicon: 1:500), anti-HIF-2 $\alpha$ (Santa Cruz Biotechnology: 1:500), anti-Glut-1 (Santa Cruz Biotechnology: 1:150), anti-iNOS (Upstate Biotechnology, Lake Placid, NY: 1:500), anti-BNIP3 (Abgent, San Diego, CA 1:100), anti-PAI-1 (Santa Cruz Biotechnology: $1: 150)$ ). Densitometry of bands was done using Image J 1.30 analysis software capturing integrated density of regions of interest and dividing these values by the unit area of the region of interest. In all cases, confirmation of equal loading was accomplished by Memcode staining (Pierce Chemical) and by probing blots against vinculin (1:4,000 Sigma).

\section{RNA Extraction and Quantitative Real-Time RT-PCR}

Total RNA was extracted from the control and treated HMEC-1 cells using the RNeasy kit (QIAGEN) immediately following the treatments. The concentration and purity of RNA samples were determined spectrophotometrically by absorbance at 260 and $280 \mathrm{~nm}$, and the integrity was confirmed by agarose gel electrophoresis. Synthesis of the first strand cDNAs, quantitative real-time PCR reactions and data analysis were then performed. Total RNA $(1 \mu \mathrm{g})$ was reverse transcribed in $50 \mu$ l reaction and $5 \mu \mathrm{l}$ of cDNA was then used for PCR reaction according to Invitrogen technical manual.

The following gene-specific primer pairs were used: $h$ if- $1 \alpha$, forward; 5'-CTGATATTAAACCTAAATGTTCTGCCTACC3', reverse; 5'-CAGTCTGCTCAAAATAT CTTTATACCAAC3'; glut-1, forward 5'-CCTAAGGATCTCTCAGGAGCACAG-3', reverse; 5'-TCAGGTTTGGAAGTCTCATCCAG- 
3'; vegf, forward; 5'-TGTATTTGAC TGCTGTGGACTTGAG3', reverse; 5'-TCAGGATCTGAGTGGGAACATTC-3', hif$2 \alpha$, forward 5'-GCGGCCGCTCACTTGTCATCGTCGTCCTTGTAGTCGGTGGCCTGGT-3', reverse; 5'ACCAGGCCACCGACTACAAGGACGACGATGACAAGTGAGCGGCCGC-3', iNOS, forward, 5'- TACTCCACCAACAATGGCAA-3', reverse, 5'GATGAGCTGAGCATTCCACA-3', hprt, forward 5'GGGAGGCCATCACATTGTAG-3', reverse, 5'-CCTGACCAAGGAAAGCAAAG-3'. Gene expression of HIF-1 $\alpha$, HIF$2 \alpha$, iNOS, Glut-1, and VEGF were quantified relative to the expression level of HPRT, a housekeeping gene. Probes for these reactions were purchased from Invitrogen (Carlsbad, CA). The difference in threshold number of cycles between the gene of interest and HPRT was then calculated and plotted as relative abundance of gene of interest over HPRT.

\section{VEGF ELISA}

VEGF levels were assessed by ELISA using a rabbit polyclonal anti-VEGF antibody (Abcam, Cambridge, MA). Supernatants from cells $(100 \mu \mathrm{l})$ were added to a high binding white ELISA plate (COSTAR, Corning, NY) together with a standard curve of recombinant human VEGF (0.1 $10,000 \mathrm{pg} / \mathrm{ml}$ ) (Biosource International, Camarillo, CA) overnight at $4^{\circ} \mathrm{C}$. The wells were washed with TBS, blocked with $1 \%$ BSA in TBS before anti-VEGF antibody was (1:1000 dilution of $1 \mathrm{mg} / \mathrm{ml}$ stock) added for 2 hours at RT, the wells washed again and 1:2000 anti-Rabbit HRP conjugate (Pierce, Rockford, IL) added for 45 minutes at RT, the wells washed again with TBS, then an ECL ELISA substrate (Pierce) added to wells for 5 minutes and the chemiluminescence measured using a plate reader (Fluostar Optima, BMG Labtechnologies, NC). Data were normalized to the standard curve to yield values in $\mathrm{pg} / \mathrm{ml}$ VEGF and graphed as percentage of untreated control.

\section{Statistics}

Data were analyzed using one-way analysis of variance to compare the means of all the groups. The Neuman-Keuls multiple comparisons procedure was used to determine which pairs of means were different. Differences were considered significant at $P<0.05$.

\section{Results}

Chronic mild decreased oxygen induces the HIF pathway Human microvascular endothelial cells (HMEC-1) were exposed to either $21 \% \mathrm{O}_{2}$ (normoxia) or to $5 \%, 7.5 \%$ and 10 and $15 \% \mathrm{O}_{2}$ for three weeks (Figure 1). Oxygen levels lower than $15 \% \mathrm{O}_{2}$ were found to result in significant decreases in endothelial cell proliferation (Figure 2). Since the goal of this paper was to examine the effect of mild

\section{Continuous normoxia ("N") or mild decreased oxygen ("D")}

$\frac{21 \text { days }}{21 \% \mathrm{O}_{2}(\mathrm{~N}) \text { or } 15 \% \mathrm{O}_{2}(\mathrm{D})}$

\section{II. "memory" of mild decreased oxygen ("D $\rightarrow N ")$}

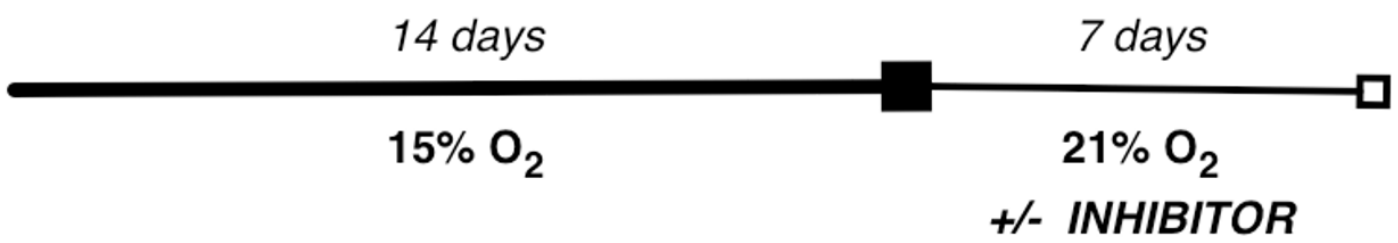

Figure I

Treatment scheme for experiments in this work. Isolated microvascular endothelial cells mild decreased oxygen (I5\% $\mathrm{O}_{2}$ ) for three weeks (I) or to mild decreased oxygen for two weeks then to normoxia for one week ("memory" treatment - II). 


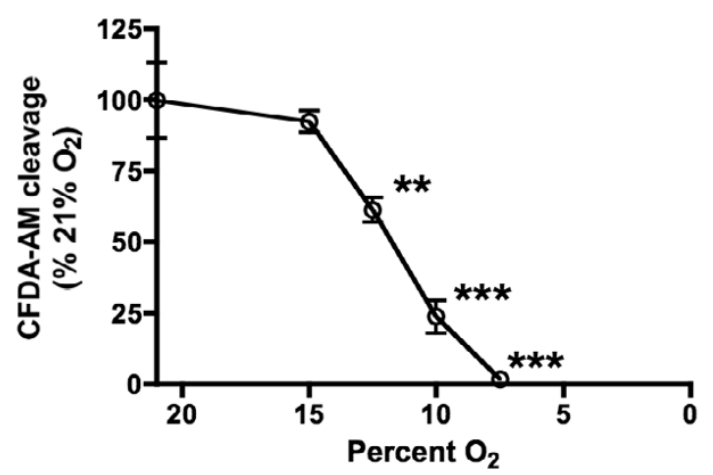

Figure 2

Effect of chronic relative hypoxia on a marker of cell proliferation in HMEC-I cells. HMEC-I cells were exposed to normoxia $(20 \%$ O2) or to various levels of relative hypoxia for 3 weeks followed by a one hour incubation with $5 \mu$ M CFDA-AM and fluorescence measurement as in methods. The data represent the mean $+/$ - SEM of triplicate wells from 3 independent experiments. $* *=P<0.01$ and $* * *$ $=\mathrm{P}<0.00 \mathrm{I}$ using one-way ANOVA with a Neuman-Keuls multiple comparisons post-test.

decreased oxygen, $15 \% \mathrm{O}_{2}$ was used for the remainder of the studies. This level of decreased oxygen is very mild in comparison with arterial oxygen levels of patients with chronic obstructive pulmonary disease [46,47], sleep apnea [48], or coronary artery disease [49].

Levels of HIF signaling proteins (Figure 3) and steadystate mRNA (Figure 4) were measured by Western blot and real-time RT-PCR, respectively. For each protein or mRNA graph, representative Western blots (for protein except for VEGF in which an ELISA was used) or RNA gels (for mRNA) are shown above graphs of densitometric analysis of bands. We found that protein levels of HIF-1 $\alpha$ and HIF- $2 \alpha$ and of the HIF target genes GLUT-1 [50], BNIP3 [51], PAI-1 [52], iNOS [53], and VEGF [54] were induced in response to chronic mild decreased oxygen (Figure 3A-G; "D" compared to "N"), although this induction was not as profound as that of the cells in response to acute hypoxia $\left(2.5 \% \mathrm{O}_{2}\right.$ for 4 hours; Figure 3A-G; ("AH")). In contrast, little effect was observed on the constitutively regulated loading protein vinculin (Figure $3 \mathrm{H}$ ). It was next found that there was no changes in HIF-1 $\alpha$ (Figure 4A) mRNA levels in response to chronic mild decreased oxygen, but that mRNA levels of the HIF target genes VEGF (Figure 4B), GLUT-1 (Figure 4C), and iNOS (Figure 4D) were induced as compared to normoxic controls.

\section{HIF induction persists after oxygen normalization}

To determine whether the induction of HIF signaling persists after oxygen levels are normalized, cells were exposed to two weeks of mild decreased oxygen followed by one week of normoxia. Unexpectedly, levels of HIF- $1 \alpha$ protein (Figure 3A) but not HIF-1 $\alpha$ mRNA (Figure 4A) remained induced one week after normalization. There was no "memory" of HIF-2 $\alpha$ protein induction (Figure $3 \mathrm{~B}$ ) but there was a "memory" of induction of the HIF target genes GLUT-1 (Figure 3C), BNIP3 (Figure 3D), PAI-1 (Figure $3 \mathrm{E}$ ), iNOS (Figure 3F) and VEGF (Figure 3G) at the protein level. This "memory" of induction was also observed for VEGF (Figure 4B), GLUT-1 (Figure 4C) and iNOS (Figure $4 \mathrm{D})$ at the mRNA level.

\section{The "memory" of HIF signaling after oxygen normalization is not cell specific}

To determine whether this "memory" of HIF induction was unique to the HMEC-1 cells, which harbor an SV40 T antigen [34], primary human umbilical vein endothelial cells (HUVECs) and human aortic vascular smooth muscle cells (ASMCs) were exposed to the same treatments as the HMEC-1 cells. Like the HMEC-1s, both an induction of HIF-1 $\alpha$ (Figure 5A, 5E) and the HIF target genes VEGF (Figure 5C, 5G) and GLUT-1 (Figure 5D, 5H) and a "memory" of that induction was observed at the protein level in both the HUVECs and ASMCs. Interestingly, an absence of induction of HIF- $2 \alpha$ was observed in the HUVECs (Figure 5B) but not in the ASMCs (Figure 5F).

\section{HIF mediates in the persistent induction of VEGF, BNIP3, PAI-I and iNOS after oxygen normalization}

It has been suggested that a major regulator of HIF signaling in response to mild decreased oxygen is not the oxygen levels themselves, but rather a cellular buildup of reactive species secondary to decreased oxygen [55]. To address this, HIF and reactive species inhibitors were added during the last week of normoxia subsequent to two weeks of mild decreased oxygen in the HUVECs. The rationale for adding agents during the normalization period is to mimic a clinical situation with a patient with previous decreased oxygen exposure. To reduce HIF levels, short hairpin RNAs (hrRNAs) against HIF were developed. Adenoviral delivery of these siRNAs was found to reduce HIF-1 $\alpha$ protein expression by $80-90 \%$ (Figure 6A). Unfortunately, all of these HIF shRNAs were found to be toxic to the cells (Figure 6B). In place of genetic manipulations, a well-characterized pharmacological agent, YC-1 [40], known to degrade the HIF-1 $\alpha$ protein [56] was chosen and doses titrated to minimize cell death. It was found that $5 \mu \mathrm{M}$ YC- 1 resulted in approximately $60 \%$ reduction in the "memory" of induction of HIF-1 $\alpha$ (Figure 7A) but not HIF-2 $\alpha$ (Figure $7 \mathrm{~B}$ ) proteins with no significant toxicity to the cells (Figure 6B). YC-1 also resulted in a similar level of reduction in the "memory" of induction of the HIF target genes VEGF (Figure 7C), BNIP3 (Figure 7D), PAI-1 (Figure 7E) and iNOS (Figure 7F), but not GLUT-1 (Figure $7 \mathrm{G}$ ) at the protein level. 

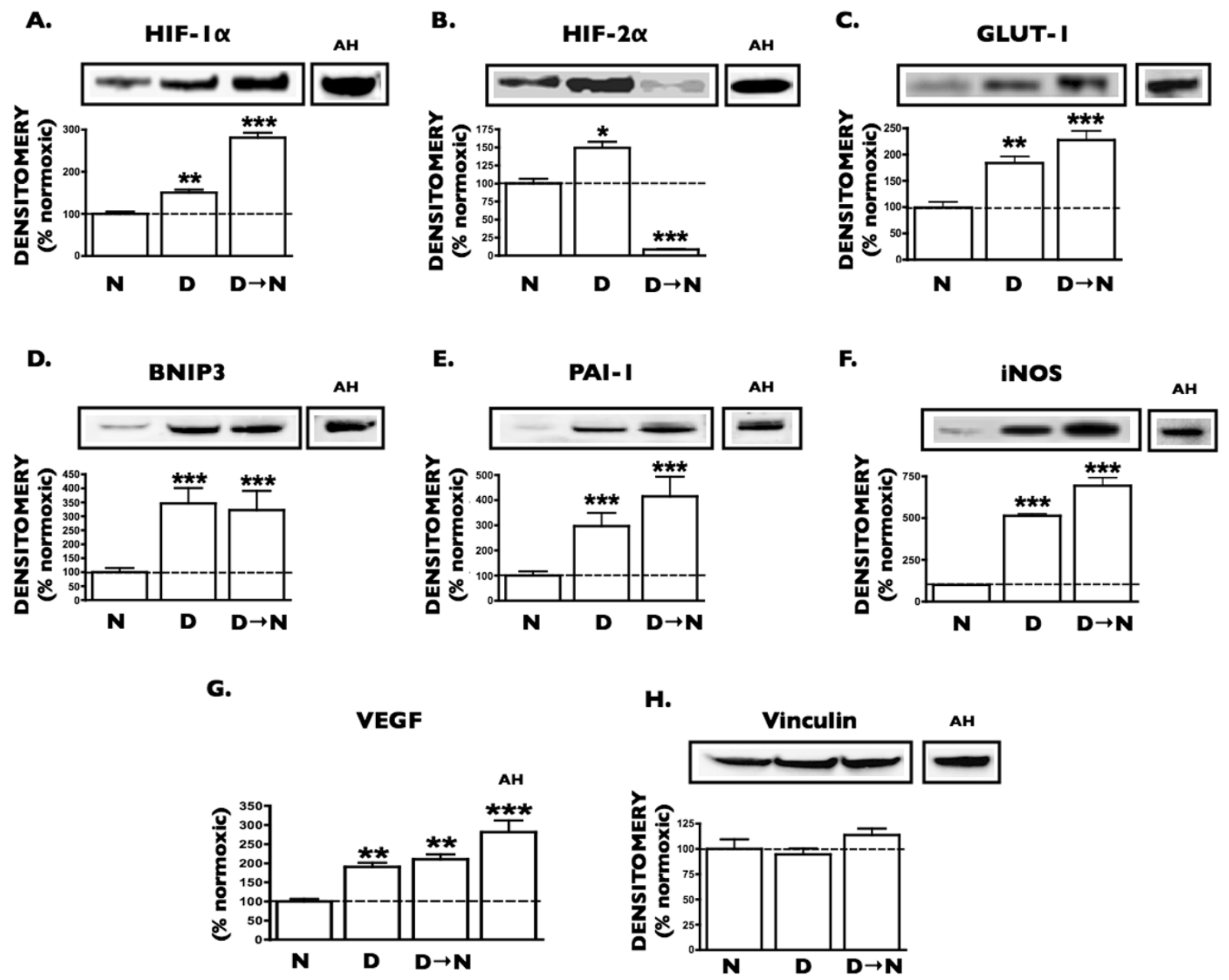

Figure 3

Effect of oxygen normalization on HIF-I $\alpha$, HIF-2 $\alpha$, Glut-I, BNIP3, PAI-I, iNOS and VEGF protein expression in human endothelial cells. Human microvascular endothelial cells were exposed as described in Figure I. Western blots were performed against HIF-I $\alpha$ (A), HIF-2 $\alpha$ (B), Glut-I (C), BNIP3 (D), PAI-I (E), iNOS (F) on cellular lysates and ELISA was performed against VEGF $(G)$ on cellular supernatants. Graphs indicate the densitometric analysis relative to the respective normoxic protein expression (dashed line) with a representative blot for each protein above each graph. Acute hypoxia $\left(2.5 \% 0_{2} ; 4\right.$ hours) ("AH") was used as a positive control for the induction of proteins. Data in graphs represent the mean +/- S.E.M. from three separate experiments with a total sample size of $4-6$. Asterisk, $P<0.05$; double asterisk, $P<0.0$ I; triple asterisk, $P<$ $0.00 \mathrm{I}$ as compared to cells incubated in normoxia for three weeks.

\section{Reactive species mediate the persistent induction of GLUT-I after oxygen normalization}

To determine whether reactive species, a key non-hypoxic regulator of signaling [55], was involved in the "memory" of HIF signaling after oxygen normalization, the general antioxidant $\alpha$-lipoic acid (ALA) [58] was added to the last week of normoxia. No change in the persistent induction of HIF-1 $\alpha$ (Figure 7A), HIF-2 $\alpha$ (Figure 7B), BNIP3 (Figure 7D), PAI-1 (Figure 7E), or iNOS (Figure 7F) proteins was observed with the addition of ALA. In contrast, a significant reduction in the persistent induction of GLUT-1 protein (Figure 7G) was observed with ALA. To examine the source of the reactive species which leading to the "memory" of GLUT-1 induction, the mitochondrial respiratory chain uncoupling protein UCP2; or the NAD $(\mathrm{P}) \mathrm{H}$ oxidase inhibitor apocynin (APO); or oxypurinol (OXY), a xanthine oxidoreductase inhibitor; or L-NAME, an NOS inhibitor; were added during the last week of normalized 
A.

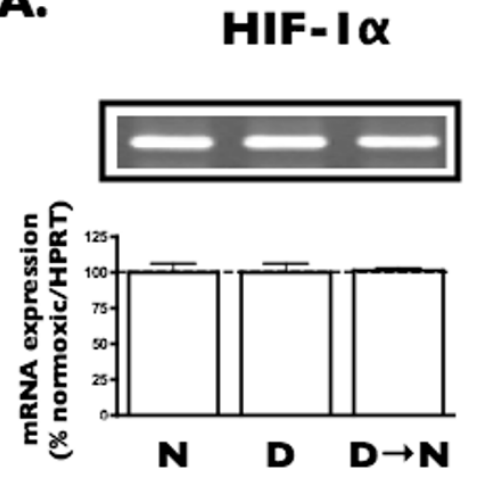

C.

GLUT- I
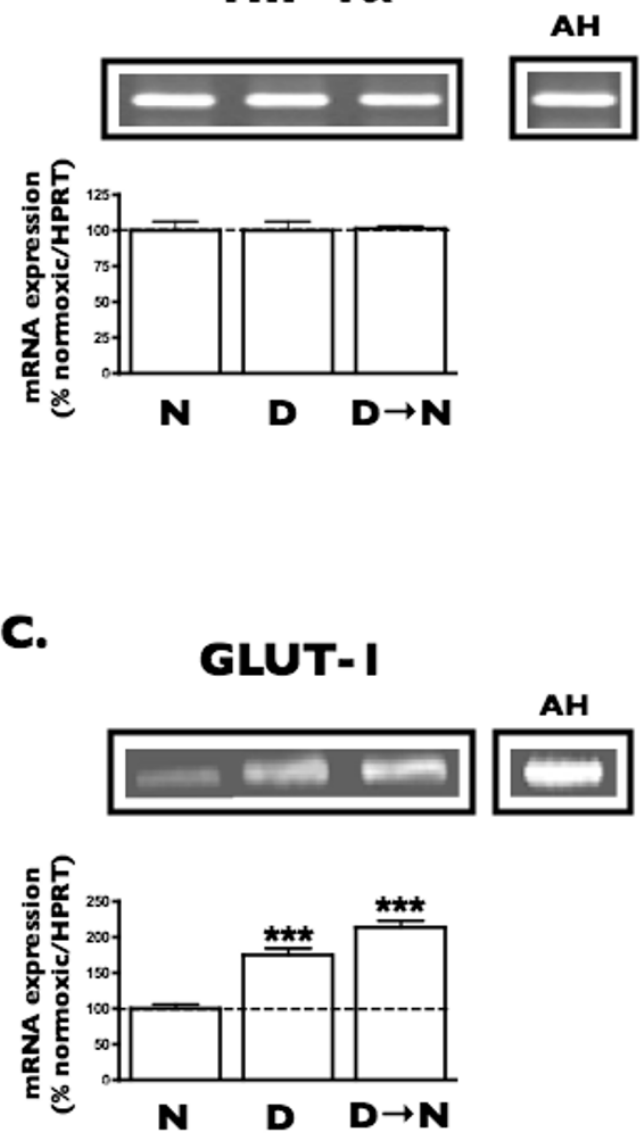

B.

VEGF

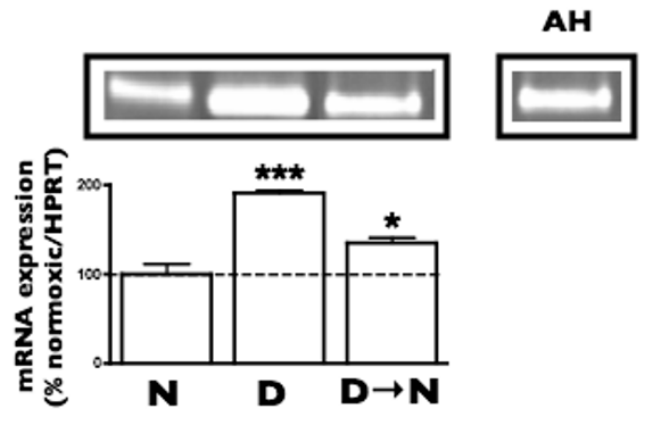

D.

iNOS
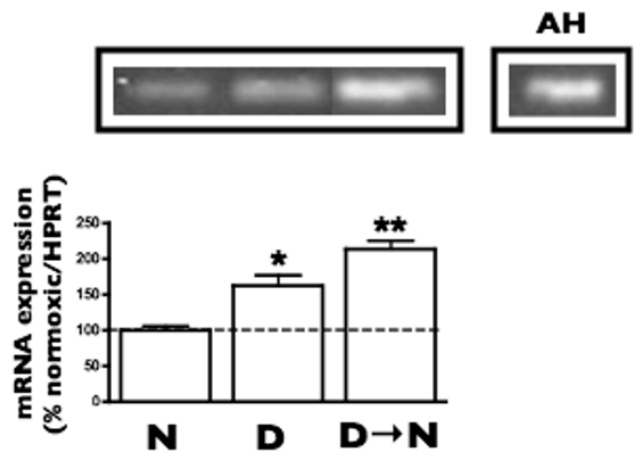

Figure 4

Effect of oxygen normalization on HIF target mRNA expression in human endothelial cells. Human microvascular endothelial cells were exposed as described in Figure I. Total RNA was extracted and the amount of HIF-I $\alpha$ (A), VEGF (B), Glut-I (C), and iNOS (D) transcripts were analyzed by quantitative real-time RT-PCR as described in Materials and Methods. In the graphs (bottom panels), all values are expressed relative to the HPRT gene expression for each condition. Acute hypoxia $\left(2.5 \% \mathrm{O}_{2} ; 4\right.$ hours- "AH") was used as a positive control for the induction of transcripts. Data in graphs represent the mean $+/-$ S.E.M. from three separate experiments with a sample size of 3-5 with representative gels above each graph. Asterisk, $P<0.05$; double asterisk, $P<0.01$; triple asterisk, $P<0.00 \mathrm{I}$ as compared to cells incubated in three weeks of normoxia $\left(21 \% \mathrm{O}_{2}\right)(\mathbf{N})$ (dashed line).

oxygen. UCP, APO and L-NAME had little effect on the "memory" of GLUT-1 protein induction (Figure 7G) whereas OXY resulted in a partial but significant interruption of GLUT-1 induction.

\section{Persistent changes in HIF-I $\alpha$ ubiquitylation in response to chronic mild decreased oxygen}

To begin to explore the mechanistic basis behind the stabilization of the HIF-1 $\alpha$ protein after oxygen normaliza- tion, the ubiquitylation of HIF-1 $\alpha$ was examined in response to mild decreased oxygen. Using immunoprecipitation (IP) against HIF-1 $\alpha$ and a Western blot against ubiquitin (Figure 8; top blot), it was found that chronic mild decreased oxygen (D) resulted in decreased ubiquitylation of HIF-1 $\alpha$ while normalization of oxygen for one week after two weeks mild decreased oxygen $(D>N)$ resulted in similar levels of ubiquitylation as cells exposed to normoxia $(\mathrm{N})$. These ubiquitin blots were then re- 


\section{HUVEC}

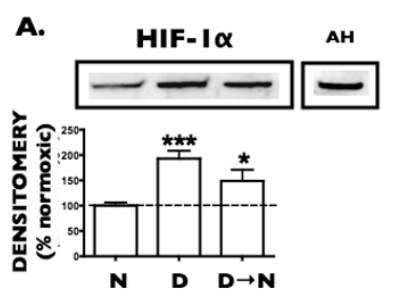

ASMC

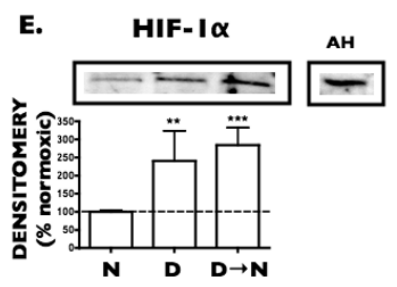

B.

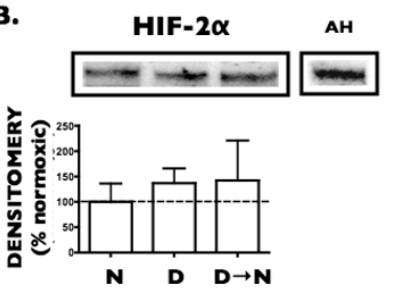

c.

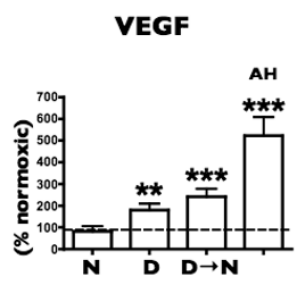

D.

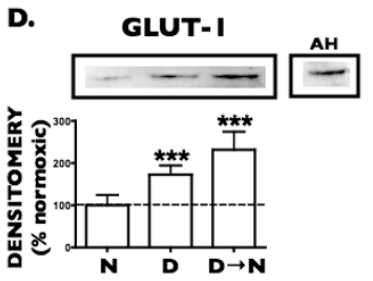

F.

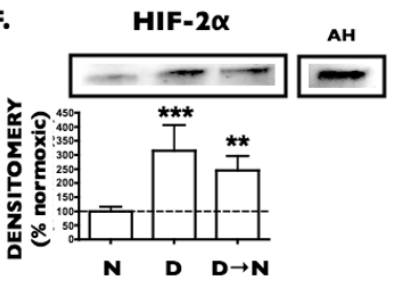

G.

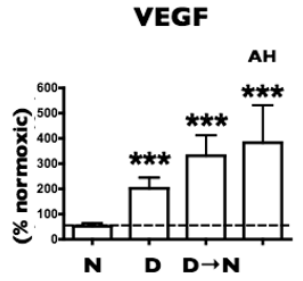

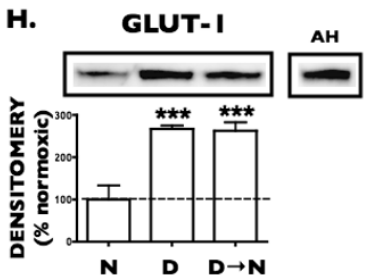

Figure 5

Effect of oxygen normalization on expression of HIF-I $\alpha$, HIF-2 $\alpha$, VEGF, and GLUT-I protein expression in HUVECs and ASMCs. HUVECs (A-D) and human ASMCs (E-H) were exposed as described in Figure I. Western blots were performed against HIF-I $\alpha$ (A and E), HIF-2 $\alpha$ (B and F), GLUT-I (D-H) on cellular lysates and ELISA was performed against VEGF ( $C$ and $G$ ) on cellular supernatants. Graphs indicate the densitometric analysis relative to the respective normoxic protein expression (dashed line) with a representative blot for each protein above each graph. Acute hypoxia $\left(2.5 \% 0_{2}\right.$; 4 hours - "AH") was used as a positive control for the induction of each of the target protein. Data in graphs represent the mean +/- S.E.M. from three separate experiments with a total sample size of 4-6 and with representative gels above each graph. Asterisk, $P<0.05$; double asterisk, $P<0.0$ I; triple asterisk, $P<0.00$ l as compared to cells incubated in normoxia for three weeks.

probed with an HIF-1 $\alpha$ antibody raised in another species (Figure 8; middle blots), and the densitometry of bands graphed as a ratio of ubiquitin:HIF-1 $\alpha$ (Figure 8; bottom graph). It was found that chronic exposure to mild decreased oxygen, and to a lesser extent mild decreased oxygen followed by one week of oxygen normalization resulted in significantly decreased ubiquitin/HIF-1 $\alpha$ ratios (Figure 8; bottom graph).

\section{Discussion}

The present study demonstrates proof-of-principle that chronic exposure to mild decreased oxygen is capable of stimulating HIF signaling and that this induction of signaling persists one week after oxygen levels are normalized. We found this "memory" of HIF signaling was not cell type-specific, being observed in two different endothelial cell types as well as in aortic SMCs. We found that degrading the HIF-1 $\alpha$ protein using the chemical YC-1 was capable of interrupting the "memory" of HIF-1 $\alpha$, VEGF, BNIP3, PAI-1 and iNOS induction and that decreasing cellular reactive species using a general antioxidant or an inhibitor of xanthine oxidoreductase was capable of interrupting the "memory" of GLUT-1 induction. Finally, we found that levels of ubiquitylated HIF- $1 \alpha$ were reduced in response to chronic mild decreased oxygen and only partially recovered after oxygen levels were normalized. As a result of these findings, we speculate that HIF signaling may be contributing to the pathogenesis of endothelial dysfunction and could be further explored be a therapeutic target in addition to oxygen normalization.

The $15 \% \mathrm{O}_{2}$ used in these studies is likely the mildest decrease in oxygen resulting in an induction of HIF signaling. This finding suggests that even such "innocuous" decreases in oxygen levels can trigger a hypoxic-like response in the endothelium. This could be a doubleedged sword in terms of propagating endothelial dysfunction. Although purely speculative at this point, the persistent increase in GLUT-1 after oxygen normalization could result in increased glucose transport into the endothelium, which could exacerbate endothelial dysfunction in diabetic patients. The persistent induction of iNOS after 

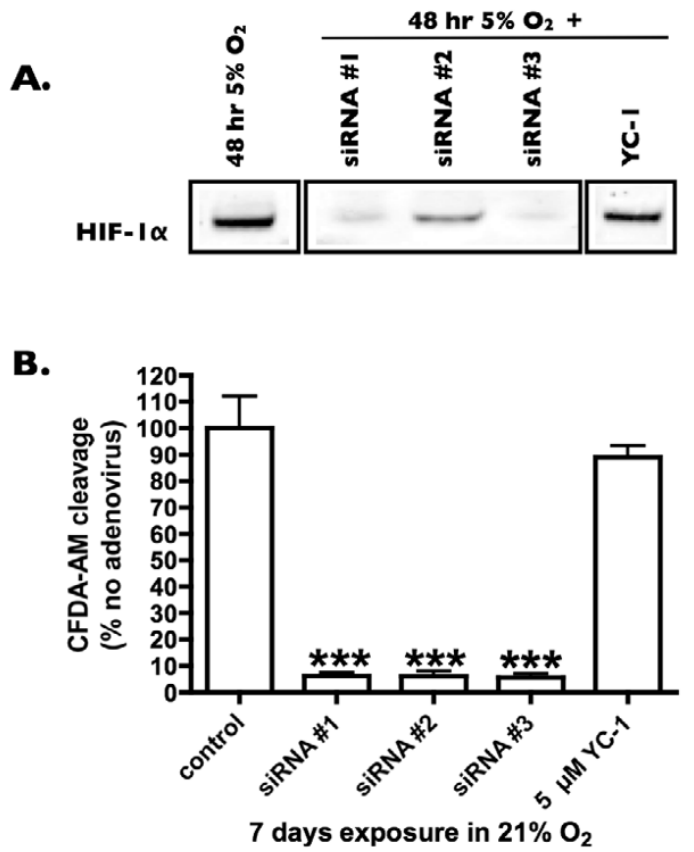

\section{Figure 6}

Effect of adenoviral siRNA on HIF-I $\alpha$ protein $(A)$ and cell proliferation (B) in HMEC-I cells. Adenoviral vectors containing hairpin siRNAs against HIF-I $\alpha$ were created as in the methods. Panel A. HMEC-I cells were infected with 50-100 PFU/cell adenovirus or $5 \mu \mathrm{M}$ YC-I, exposed to $5 \%$ $\mathrm{O}_{2}$ for 48 hours then cell lysates made and HIF-I $\alpha$ protein expression assessed by Western blot. Representative bands for HIF-I $\alpha$ are shown. Panel B. HMEC-I cells were infected with adenovirus or treated with $5 \mu \mathrm{M}$ YC-I every 3 days for 7 days and cell proliferation assessed using the CFDA-AM assay as in methods. The data represent the mean +/- SEM of triplicate wells from 3 independent experiments. $* * *=\mathrm{P}<$ 0.001 using one-way ANOVA with a Neuman-Keuls multiple comparisons post-test.

oxygen normalization may increase $\mathrm{NO}$ available for vasodilation, but more likely the excess $\mathrm{NO}$ would combine with reactive oxygen species to form reactive nitrogen species, and again could worsen endothelial dysfunction [59]. The "memory" of VEGF induction after oxygen normalization could also be a double-edged sword, with the appropriate amount of VEGF facilitating neovascularization and an excess of VEGF leading to ill-formed vessels [60] and to increased vascular permeability and leukocyte infiltration [61]. Finally, high levels of PAI-1 have been found to be associated with cardiovascular disease [62], and BNIP3 has been found to be a mediator of myocardial death after infarction [63], again allowing one to surmise that the induction of these two HIF target genes could affect endothelial dysfunction.
In this work, both HIF $\alpha$ subunits were found to respond similarly to chronic mild decreased oxygen exposure, however, a "memory" of HIF- $1 \alpha$, but not HIF- $2 \alpha$ was observed after one week of normalized oxygen levels following two weeks of mild decreased oxygen in both the microvascular (Figure 3) and umbilical vein (Figure 5) endothelial cells. In the aortic smooth muscle cells, however, a "memory" of HIF- $2 \alpha$ protein induction was observed (Figure 5). This suggests, as others have implied, a differential regulation of these two HIF $\alpha$ subunits in response to certain stressors and in specific cell types $[64,65,63,66]$. This also supports the predominance of HIF- $1 \alpha$ as compared to HIF- $2 \alpha$ in some systems for regulating gene expression in response to decreased oxygen $[67-69,66,62,64,70]$. Although not examined in these studies, a decrease the endogenous HIF inhibitor HIF-3 $\alpha$ [18] could also explain the cellular "memory" of HIF induction and ongoing studies in our laboratory are directed toward understanding the role of this protein in response to chronic mild decreased oxygen.

The "memory" of GLUT-1 induction after oxygen normalization was found to be mediated at least in part by reactive species, with an inhibitor of reactive species production through xanthine oxidoreductase resulting in a significant interruption of GLUT-1 "memory" (Figure $7 \mathrm{G})$. This finding is supported by the work of Kelley et al. [70], who found that moderate hypoxia $\left(\begin{array}{lll}10 \% & \mathrm{O}_{2}\end{array}\right)$ resulted in the induction of xanthine oxidoreductase in endothelial cells. An alternative to explain the cellular "memory" HIF induction could be that the re-oxygenation itself is stimulating HIF, perhaps via an increase in reactive species. While the addition of reactive species inhibitors and scavengers during the oxygen normalization period (Figure 7G) appears to rule this out in all cases except perhaps GLUT-1, this would be another interesting area of exploration. The addition of reactive species donors or other compounds like pro-inflammatory cytokines which increase reactive species together with the measurement of reactive species markers like 3-nitrotyrosine [71] and esterified glutathione [20] could be used to further address these issues.

The canonical mechanism of HIF induction in response to hypoxia, however, is not through reactive species but rather through HIF prolyl hydroxylase (HPH), enzymes, which target HIF $\alpha$ subunits for ubiquitylation and ultimate degradation by the proteasome and which are rendered inactive in response to low oxygen [72]. Based on many previous reports, it seemed improbable that the mild decreased oxygen $\left(15 \% \mathrm{O}_{2}\right)$ used in this study is low enough to act through this mechanism [22, 72, 73]. Our results with ubiquitylated HIF-1 $\alpha$ (Figure 8), however, suggest that HIF- $1 \alpha$ ubiquitylation is reduced in response to chronic mild decreased oxygen and that ubiquitylation 
A.

HIF-I $\alpha$

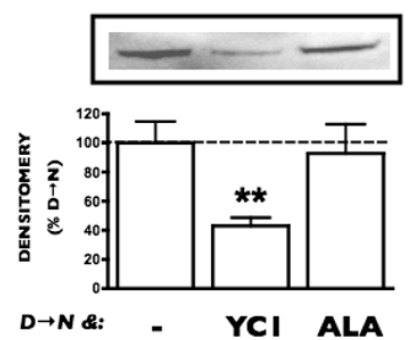

D.

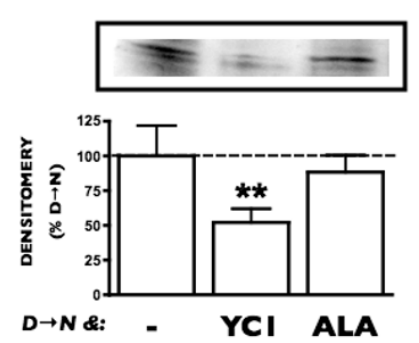

B.

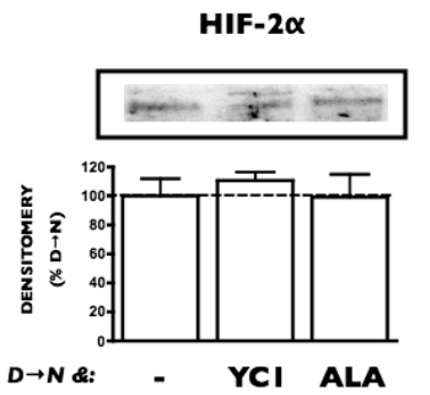

E.

PAI- I

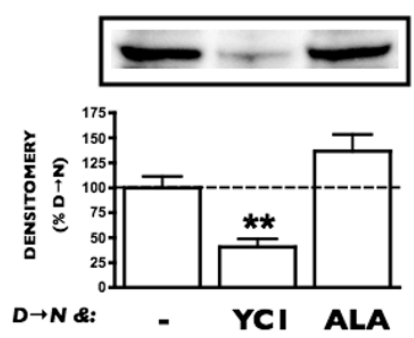

c.

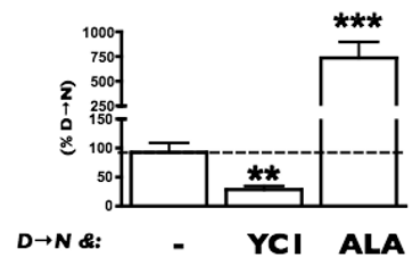

F.

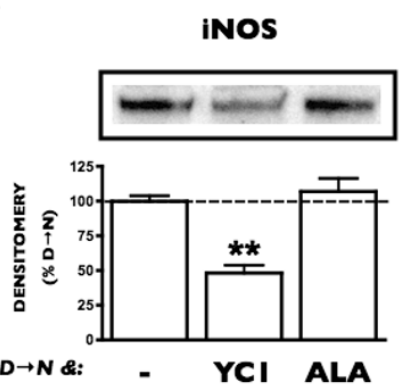

G.

GLUT- I

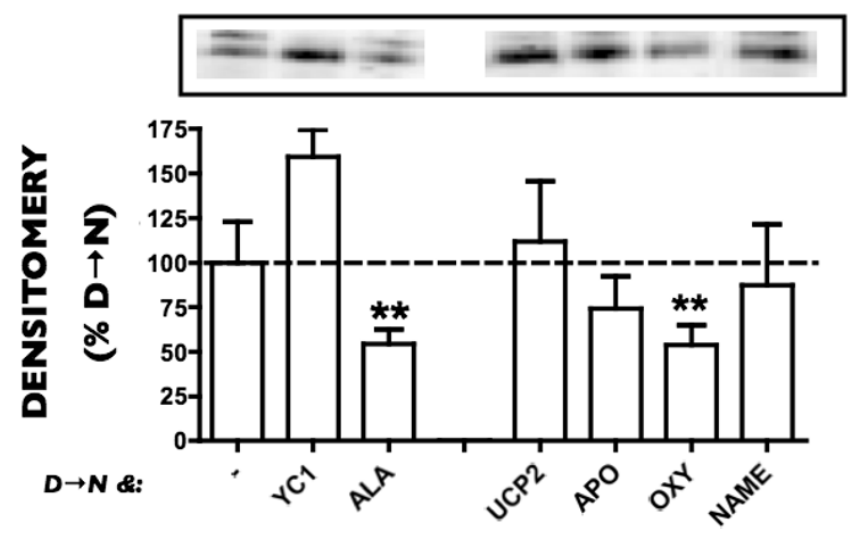

Figure 7

Effect of various inhibitors and anti-oxidants on "memory" for HIF-I $\alpha$, HIF-2 $\alpha$, Glut-I, BNIP3, PAI-I, iNOS and VEGF expression in human endothelial cells. HUVECs were exposed to two weeks of mild decreased oxygen followed by one weeks of normoxia $(\mathbf{D} \rightarrow \mathbf{N})$ in the presence or absence of $5 \mu \mathrm{M}$ of the HIF inhibitor YC-I, or $62.5 \mu \mathrm{M} \alpha$-lipoic acid (ALA), or 25-100 PFU/cell UCP2 adenovirus, or $10 \mu \mathrm{M}$ apocynin (APO), or $10 \mu \mathrm{M}$ oxypurinol (OXY) or to I mM LNAME. Western blots were performed against HIF-I $\alpha(A)$, HIF-2 $\alpha$ (B), BNIP3 (D), PAI-I (E), iNOS (F) and GLUT-I (G) on cellular lysates and ELISA was performed against VEGF (C) on cellular supernatants. Graphs for each Western blot indicate the densitometric analysis relative to the respective "memory" (D $\rightarrow \mathbf{N}$ ) protein expression (dashed line). Data in graphs represent the mean +/- S.E.M. from three separate experiments with a total sample size of 4-6 and with representative gels above each graph. Double asterisk, $P<0.0$ I; triple asterisk, $P<0.00$ I as compared to cells in "memory" (D $\rightarrow \mathbf{N})$ treatment. 

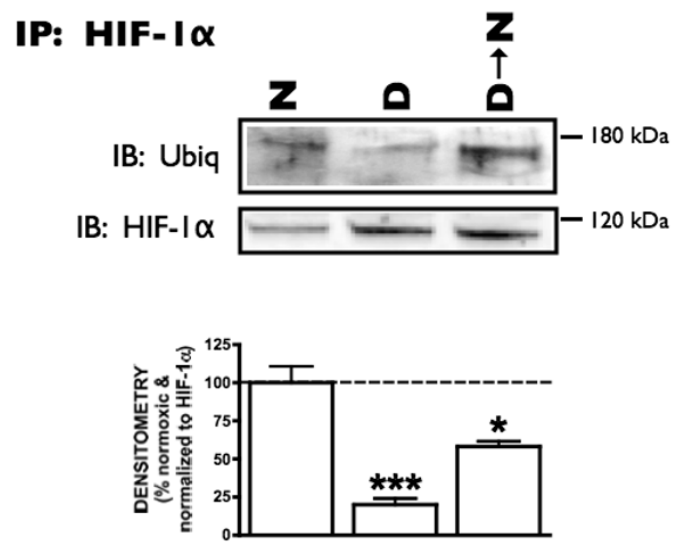

\section{Figure 8}

Effect of the transition from mild hypoxia to normoxia on the ubiquitylation of HIF- $\alpha$. HUVECs were exposed to mild decreased oxygen as in Figure I. Whole cell lysates were co-immunoprecipitated against HIF-I $\alpha$ and Western blot against ubiquitin (top panel) and HIF-I $\alpha$ (bottom panel) completed as in Materials and Methods. Densitometric analysis of ubiquitin expression in HUVECs graphed as a percentage of normoxic ubiquitin expression (dashed line). Data represent the mean $+/$ - S.E.M. from three separate experiments with a total sample size of $4-6$. Asterisk, $P<$ 0.05 ; triple asterisk, $P<0.00 \mathrm{I}$ as compared to cells incubated in normoxia for three weeks.

only partially recovers one week after oxygen levels were normalized. Ongoing work in our laboratory is seeking to examine whether the modification of HIF- $1 \alpha$ by HPHs or whether the ubiquitylation of hydroxylated HIF- $1 \alpha$ is the target for HIF stabilization in response to chronic mild decreased oxygen and upon oxygen normalization.

\section{Conclusion}

In summary, our results provide a proof-of-principle that hypoxic signaling through HIF is induced in response to chronic mild decreased oxygen and that this induction persists long after oxygen levels are normalized. This work implies that the HIF system could be a relevant therapeutic target in the treatment of endothelial dysfunction. This work also upholds and extends a possible role of reactive species in the formation of endothelial dysfunction and bolsters the use of antioxidants and xanthine oxidoreductase inhibitors in the treatment of vascular disease in addition to oxygen normalization.

\section{Competing interests}

The authors declare that they have no competing interests.

\section{Authors' contributions}

CDK participated in the design of the studies, the experiments for figures 1-2, interpretation of data, statistical analysis, produced a first draft of the manuscript with JET, and was involved in subsequent drafts of the manuscript.

JET participated in the design of the studies, the experiments for figures 3, 4, 5, interpretation of data, statistical analysis, produced a first draft of the manuscript with $\mathrm{CDK}$, and was involved in subsequent drafts of the manuscript.

SSS participated in the design of the studies, cell culture experiments, statistical analysis, and drafting of the manuscript.

AC, together with MAI, came up with the concept for a cellular "memory" of hypoxic stress signaling, designed the experiments, and was participated in drafting of the manuscript.

DEG participated in the cell culture studies and drafting of the manuscript.

LAW participated in the cell culture studies and drafting of the manuscript.

MAI, together with $\mathrm{AC}$, came up with the concept of the cellular "memory" of hypoxic stress signaling, designed the studies, was intimately involved in data interpretation, statistical analysis, and in all phases of writing this manuscript.

All authors read and approved the final manuscript.

\section{Acknowledgements}

This study was funded by a NIH/NCRR Center for Biomedical Research Excellence program project "Mentoring Vision Research in Oklahoma" (IP20RR0I7703-0I) to M.A.I. (promising junior investigator).

\section{References}

I. Landmesser U, Hornig B, Drexler H: Endothelial function: a critical determinant in atherosclerosis? Circulation 2004, 109(21 Suppl I):II27-33.

2. Aronson D, Rayfield EJ, Chesebro JH: Mechanisms determining course and outcome of diabetic patients who have had acute myocardial infarction. Ann Intern Med 1997, I 26(4):296-306.

3. Bugiardini R, Manfrini O, Pizzi C, Fontana F, Morgagni G: Endothelial function predicts future development of coronary artery disease: a study of women with chest pain and normal coronary angiograms. Circulation 2004, 109(21):2518-2523. 
4. Britland ST, Young RJ, Sharma AK, Clarke BF: Relationship of endoneurial capillary abnormalities to type and severity of diabetic polyneuropathy. Diabetes 1990, 39(8):909-9|3.

5. Farhangkhoee H, Khan ZA, Kaur H, Xin X, Chen S, Chakrabarti S: Vascular endothelial dysfunction in diabetic cardiomyopathy: Pathogenesis and potential treatment targets. Pharmacol Ther 2005.

6. Guay AT: Relation of endothelial cell function to erectile dysfunction: implications for treatment. Am J Cardiol 2005, 96(I 2B):52M-56M.

7. Szocs K: Endothelial dysfunction and reactive oxygen species production in ischemia/reperfusion and nitrate tolerance. Gen Physiol Biophys 2004, 23(3):265-295.

8. Meraji S, Jayakody L, Senaratne MP, Thomson AB, Kappagoda T: Endothelium-dependent relaxation in aorta of BB rat. Diabetes 1987, 36(8):978-98।.

9. Schmetterer L, Findl O, Fasching P, Ferber W, Strenn K, Breiteneder $\mathrm{H}$, Adam H, Eichler HG, Wolzt M: Nitric oxide and ocular blood flow in patients with IDDM. Diabetes 1997, 46(4):653-658.

10. Soriano FG, Virag L, Szabo C: Diabetic endothelial dysfunction: role of reactive oxygen and nitrogen species production and poly(ADP-ribose) polymerase activation. J Mol Med 200I, 79(8):437-448.

II. Felmeden DC, Lip GY: Endothelial function and its assessment. Expert Opin Investig Drugs 2005, I 4(I I): I3 I9-1336.

12. Catrina SB, Okamoto K, Pereira T, Brismar K, Poellinger L: Hyperglycemia regulates hypoxia-inducible factor-lalpha protein stability and function. Diabetes 2004, 53( I 2):3226-3232.

13. Higashi Y, Nishioka K, Umemura T, Chayama K, Yoshizumi M: Oxidative stress, endothelial function and angiogenesis induced by cell therapy and gene therapy. Curr Pharm Biotechnol 2006, 7(2):109-116.

14. Dery MA, Michaud MD, Richard DE: Hypoxia-inducible factor I: regulation by hypoxic and non-hypoxic activators. Int J Biochem Cell Biol 2005, 37(3):535-540.

15. Wang GL, Jiang BH, Rue EA, Semenza GL: Hypoxia-inducible factor $I$ is a basic-helix-loop-helix-PAS heterodimer regulated by cellular 02 tension. Proc Natl Acad Sci U S A 1995, 92(I2):5510-55|4.

16. Yu F, White SB, Zhao Q, Lee FS: HIF-Ialpha binding to VHL is regulated by stimulus-sensitive proline hydroxylation. Proc Natl Acad Sci U S A 200I, 98(17):9630-9635.

17. Maxwell PH, Wiesener MS, Chang GW, Clifford SC, Vaux EC, Cockman ME, Wykoff CC, Pugh CW, Maher ER, Ratcliffe PJ: The tumour suppressor protein VHL targets hypoxia-inducible factors for oxygen-dependent proteolysis. Nature 1999, 399(6733):27|-275.

18. Hara S, Hamada J, Kobayashi C, Kondo Y, Imura N: Expression and characterization of hypoxia-inducible factor (HIF)-3alpha in human kidney: suppression of HIF-mediated gene expression by HIF-3alpha. Biochem Biophys Res Commun 200I, 287(4):808-8I3.

19. Semenza GL: Angiogenesis in ischemic and neoplastic disorders. Annu Rev Med 2003, 54:17-28.

20. Haddad JJ, Olver RE, Land SC: Antioxidant/pro-oxidant equilibrium regulates $\mathrm{HIF}$ - I alpha and NF-kappa $B$ redox sensitivity. Evidence for inhibition by glutathione oxidation in alveolar epithelial cells. J Biol Chem 2000, 275(28):2। I30-2। I39.

21. Chandel NS, McClintock DS, Feliciano CE, Wood TM, Melendez JA, Rodriguez AM, Schumacker PT: Reactive oxygen species generated at mitochondrial complex III stabilize hypoxia-inducible factor-I alpha during hypoxia: a mechanism of $\mathrm{O} 2$ sensing. J Biol Chem 2000, 275(33):25। 30-25I38.

22. Hagen T, Taylor CT, Lam F, Moncada S: Redistribution of intracellular oxygen in hypoxia by nitric oxide: effect on HIF I alpha. Science 2003, 302(5652): $1975-1978$.

23. Duyndam MC, Hulscher TM, Fontijn D, Pinedo HM, Boven E: Induction of vascular endothelial growth factor expression and hypoxia-inducible factor Ialpha protein by the oxidative stressor arsenite. J Biol Chem 200I, 276(5 I):48066-48076.

24. Salnikow K, Blagosklonny MV, Ryan H, Johnson R, Costa M: Carcinogenic nickel induces genes involved with hypoxic stress. Cancer Res 2000, 60(1):38-41.

25. Hellwig-Burgel T, Rutkowski K, Metzen E, Fandrey J, Jelkmann W: Interleukin-I beta and tumor necrosis factor-alpha stimulate
DNA binding of hypoxia-inducible factor-I. Blood 1999 , 94(5): $156 \mid-1567$

26. Jiang BH, Jiang G, Zheng JZ, Lu Z, Hunter T, Vogt PK: Phosphatidylinositol 3-kinase signaling controls levels of hypoxia-inducible factor I. Cell Growth Differ 200 I, I 2(7):363-369.

27. Richard DE, Berra E, Gothie E, Roux D, Pouyssegur J: p42/p44 mitogen-activated protein kinases phosphorylate hypoxiainducible factor Ialpha (HIF-Ialpha) and enhance the transcriptional activity of HIF-I. J Biol Chem 1999, 274(46):3263I-32637.

28. Roy S, Sala R, Cagliero E, Lorenzi M: Overexpression of fibronectin induced by diabetes or high glucose: phenomenon with a memory. Proc Natl Acad Sci U S A 1990, 87(1):404-408.

29. Effect of intensive therapy on the microvascular complications of type I diabetes mellitus. Jama 2002, 287(19):2563-2569.

30. Sustained effect of intensive treatment of type I diabetes mellitus on development and progression of diabetic nephropathy: the Epidemiology of Diabetes Interventions and Complications (EDIC) study. Jama 2003, 290( I6):2159-2167.

3I. Dilsizian V, Bateman TM, Bergmann SR, Des Prez R, Magram MY, Goodbody AE, Babich JW, Udelson JE: Metabolic imaging with beta-methyl-p-[( I 23)I]-iodophenyl-pentadecanoic acid identifies ischemic memory after demand ischemia. Circulation 2005, I I 2(14):2169-2 I74.

32. Strandberg TE, Pyorala K, Cook TJ, Wilhelmsen L, Faergeman O, Thorgeirsson G, Pedersen TR, Kjekshus J: Mortality and incidence of cancer during 10-year follow-up of the Scandinavian Simvastatin Survival Study (4S). Lancet 2004, 364(9436):77I-777.

33. Bosch J, Lonn E, Pogue J, Arnold JM, Dagenais GR, Yusuf S: Longterm effects of ramipril on cardiovascular events and on diabetes: results of the HOPE study extension. Circulation 2005, I I2(9): I339-1346.

34. Ades EW, Candal FJ, Swerlick RA, George VG, Summers S, Bosse DC Lawley TJ: HMEC-I: establishment of an immortalized human microvascular endothelial cell line. J Invest Dermatol 1992, 99(6):683-690.

35. Wang GL, Semenza GL: Characterization of hypoxia-inducible factor I and regulation of DNA binding activity by hypoxia. J Biol Chem 1993, 268(29):21513-21518.

36. Wang GL, Semenza GL: Desferrioxamine induces erythropoietin gene expression and hypoxia-inducible factor I DNAbinding activity: implications for models of hypoxia signal transduction. Blood 1993, 82(12):3610-3615.

37. Bierhaus A, Chevion S, Chevion M, Hofmann M, Quehenberger $P$, Illmer T, Luther T, Berentshtein E, Tritschler H, Muller M, Wahl P, Ziegler R, Nawroth PP: Advanced glycation end productinduced activation of NF-kappaB is suppressed by alphalipoic acid in cultured endothelial cells. Diabetes 1997, 46(9): | $48 \mid-1490$.

38. Barchowsky A, Klei LR, Dudek EJ, Swartz HM, James PE: Stimulation of reactive oxygen, but not reactive nitrogen species, in vascular endothelial cells exposed to low levels of arsenite. Free Radic Biol Med 1999, 27( I I-I 2): | 405-| 4 I2.

39. Zou MH, Klein T, Pasquet JP, Ullrich V: Interleukin Ibeta decreases prostacyclin synthase activity in rat mesangial cells via endogenous peroxynitrite formation. Biochem J 1998, 336 ( Pt 2):507-5I2.

40. Yeo EJ, Chun YS, Cho YS, Kim J, Lee JC, Kim MS, Park JW: YC-I: a potential anticancer drug targeting hypoxia-inducible factor I. J Natl Cancer Inst 2003, 95(7):516-525.

4I. Zou MH, Kirkpatrick SS, Davis BJ, Nelson JS, Wiles WG, Schlattner $U$, Neumann D, Brownlee M, Freeman MB, Goldman MH: Activation of the AMP-activated protein kinase by the anti-diabetic drug metformin in vivo. Role of mitochondrial reactive nitrogen species. J Biol Chem 2004, 279(42):43940-4395I.

42. Jiang M, Wang B, Wang C, He B, Fan H, Guo TB, Shao Q, Gao L, Liu $Y$ : Inhibition of hypoxia-inducible factor-I alpha and endothelial progenitor cell differentiation by adenoviral transfer of small interfering RNA in vitro. J Vasc Res 2006, 43(6):5II-52I.

43. Pore N, Liu S, Shu HK, Li B, Haas-Kogan D, Stokoe D, Milanini-Mongiat J, Pages G, O'Rourke DM, Bernhard E, Maity A: Sp I is involved in Akt-mediated induction of VEGF expression through an HIF-I-independent mechanism. Mol Biol Cell 2004, I5(I I):484|-4853. 
44. Zhang $X$, Kon $\mathrm{T}$, Wang $\mathrm{H}$, Li F, Huang $\mathrm{Q}$, Rabbani ZN, Kirkpatrick JP, Vujaskovic Z, Dewhirst MW, Li CY: Enhancement of hypoxiainduced tumor cell death in vitro and radiation therapy in vivo by use of small interfering RNA targeted to hypoxiainducible factor-Ialpha. Cancer Res 2004, 64(22):8I39-8I 42.

45. Hurst RE, Kamat CD, Kyker KD, Green DE, Ihnat MA: A novel multidrug resistance phenotype of bladder tumor cells grown on Matrigel or SiS gel. Cancer Lett 2005, 217(2): I7I- I 80.

46. Timms RM, Kvale PA, Anthonisen NR, Boylen CT, Cugell DW, Petty TL, Williams GW: Selection of patients with chronic obstructive pulmonary disease for long-term oxygen therapy. In JAMA Volume 245. Issue 24 UNITED STATES ; | 98|:25|4-25।5.

47. Young IH, Woolcock AJ: Arterial blood gas tension changes at the start of exercise in chronic obstructive pulmonary disease. In Am Rev Respir Dis Volume 119. Issue 2 UNITED STATES; 1979:213-22I.

48. Shepard JW: Gas exchange and hemodynamics during sleep. In Med Clin North Am Volume 69. Issue 6 UNITED STATES ; 1985: I243-1264.

49. Strickland RA, Hill TR, Zaloga GP: Bedside analysis of arterial blood gases and electrolytes during and after cardiac surgery. J Clin Anesth 1989, I(4):248-252

50. Gleadle JM, Ratcliffe PJ: Induction of hypoxia-inducible factor-I, erythropoietin, vascular endothelial growth factor, and glucose transporter-I by hypoxia: evidence against a regulatory role for Src kinase. Blood 1997, 89(2):503-509.

5I. Bruick RK: Expression of the gene encoding the proapoptotic Nip3 protein is induced by hypoxia. Proc Natl Acad Sci U S A 2000, 97( I6):9082-9087.

52. Kietzmann $T$, Roth $U$, Jungermann K: Induction of the plasminogen activator inhibitor-I gene expression by mild hypoxia via a hypoxia response element binding the hypoxia-inducible factor-I in rat hepatocytes. Blood I999, 94(I 2):4I77-4I85.

53. Melillo G, Taylor LS, Brooks A, Musso T, Cox GW, Varesio L: Functional requirement of the hypoxia-responsive element in the activation of the inducible nitric oxide synthase promoter by the iron chelator desferrioxamine. I Biol Chem 1997, 272(18): I 2236-I2243.

54. Liu Y, Cox SR, Morita T, Kourembanas S: Hypoxia regulates vascular endothelial growth factor gene expression in endothelial cells. Identification of a $5^{\prime}$ enhancer. Circ Res 1995, 77(3):638-643.

55. Kietzmann T, Gorlach A: Reactive oxygen species in the control of hypoxia-inducible factor-mediated gene expression. Semin Cell Dev Biol 2005, I6(4-5):474-486.

56. Kim HL, Yeo EJ, Chun YS, Park JW: A domain responsible for HIF-I alpha degradation by YC-I, a novel anticancer agent. Int J Oncol 2006, 29(I):255-260.

57. Smith AR, Shenvi SV, Widlansky M, Suh JH, Hagen TM: Lipoic acid as a potential therapy for chronic diseases associated with oxidative stress. Curr Med Chem 2004, I I (9): I I35- I I 46.

58. Naseem KM: The role of nitric oxide in cardiovascular diseases. Mol Aspects Med 2005, 26(I-2):33-65.

59. Dvorak HF, Brown LF, Detmar M, Dvorak AM: Vascular permeability factor/vascular endothelial growth factor, microvascular hyperpermeability, and angiogenesis. Am J Pathol 1995, I 46(5): 1029-1039.

60. Detmar M, Brown LF, Schon MP, Elicker BM, Velasco P, Richard L, Fukumura D, Monsky W, Claffey KP, Jain RK: Increased microvascular density and enhanced leukocyte rolling and adhesion in the skin of VEGF transgenic mice. J Invest Dermatol 1998, III(I):I-6.

61. Vaughan DE: PAI-I and atherothrombosis. J Thromb Haemost 2005, 3(8): 1879-1883.

62. Kubasiak LA, Hernandez OM, Bishopric NH, Webster KA: Hypoxia and acidosis activate cardiac myocyte death through the $\mathrm{Bcl}-$ 2 family protein BNIP3. Proc Natl Acad Sci U S A 2002, 99(20): 12825-12830.

63. Raval RR, Lau KW, Tran MG, Sowter HM, Mandriota SJ, Li JL, Pugh CW, Maxwell PH, Harris AL, Ratcliffe PJ: Contrasting properties of hypoxia-inducible factor I (HIF-I) and HIF-2 in von Hippel-Lindau-associated renal cell carcinoma. Mol Cell Biol 2005, 25(13):5675-5686.

64. Sowter HM, Raval RR, Moore JW, Ratcliffe PJ, Harris AL: Predominant role of hypoxia-inducible transcription factor (Hif)-
I alpha versus Hif-2alpha in regulation of the transcriptional response to hypoxia. Cancer Res 2003, 63(19):6130-6134.

65. Wang V, Davis DA, Haque M, Huang LE, Yarchoan R: Differential gene up-regulation by hypoxia-inducible factor-Ialpha and hypoxia-inducible factor-2alpha in HEK293T cells. Cancer Res 2005, 65(8):3299-3306.

66. Sowter HM, Ratcliffe PJ, Watson P, Greenberg AH, Harris AL: HIFI-dependent regulation of hypoxic induction of the cell death factors BNIP3 and NIX in human tumors. Cancer Res 200I, 6I(18):6669-6673.

67. Calvani M, Rapisarda A, Uranchimeg B, Shoemaker RH, Melillo G: Hypoxic induction of a HIF-I \{alpha\}- dependent bFGF autocrine loop drives angiogenesis in human endothelial cells. Blood 2005.

68. Carroll VA, Ashcroft M: Role of hypoxia-inducible factor (HIF)Ialpha versus HIF-2alpha in the regulation of HIF target genes in response to hypoxia, insulin-like growth factor-I, or loss of von Hippel-Lindau function: implications for targeting the HIF pathway. Cancer Res 2006, 66(I 2):6264-6270.

69. Kelley EE, Hock T, Khoo NK, Richardson GR, Johnson KK, Powell PC, Giles GI, Agarwal A, Lancaster JRJ, Tarpey MM: Moderate hypoxia induces xanthine oxidoreductase activity in arterial endothelial cells. Free Radic Biol Med 2006, 40(6):952-959.

70. Radi R: Nitric oxide, oxidants, and protein tyrosine nitration. Proc Natl Acad Sci U S A 2004, I 0 I ( I 2):4003-4008.

7I. Appelhoff RJ, Tian YM, Raval RR, Turley H, Harris AL, Pugh CW, Ratcliffe PJ, Gleadle JM: Differential function of the prolyl hydroxylases PHDI, PHD2, and PHD3 in the regulation of hypoxiainducible factor. J Biol Chem 2004, 279(37):38458-38465.

72. Callapina M, Zhou J, Schmid T, Kohl R, Brune B: NO restores HIFI alpha hydroxylation during hypoxia: role of reactive oxygen species. Free Radic Biol Med 2005, 39(7):925-936.

\section{Pre-publication history}

The pre-publication history for this paper can be accessed here:

http://www.biomedcentral.com/1471-2261/7/4/prepub

Publish with Biomed Central and every scientist can read your work free of charge

"BioMed Central will be the most significant development for disseminating the results of biomedical research in our lifetime. "

Sir Paul Nurse, Cancer Research UK

Your research papers will be:

- available free of charge to the entire biomedical community

- peer reviewed and published immediately upon acceptance

- cited in PubMed and archived on PubMed Central

- yours - you keep the copyright
BioMedcentral 